\title{
A DIFUSÃO DO CONHECIMENTO E SUA INCLUSÃO NA SOCIEDADE
}

\author{
Márcea Andrade Sales
}

Autora para correspondência: Márcea Andrade Sales - masales@uneb.br Doutora em Educação. Professora na Universidade do Estado da Bahia. Representante das Universidades estaduais no Fórum de Mestrados Profissionais em Educação - FOMPE. Salvador, Bahia, Brasil.

O debate sobre a difusão do conhecimento, no Brasil, nas últimas décadas, trilhou caminhos próprios da multipolaridade contemporânea, e buscou superar questões centradas no modelo de pesquisa impregnado, ainda, pela racionalidade técnica e suas repercussões no conhecimento científico. Finalizamos o século $\mathrm{XX}$, valorizando a pluralidade e as identidades profissionais e, passada a primeira década do século XXI esse debate foi ampliado e outras formas de fazer e pensar (n)o mundo foram reorganizadas.

As Instituições de Ensino Superior - IES são produtoras de grande volume de conhecimento científico, em processo de geração contínuo. Contudo, parte desse conhecimento ainda é pouco sistematizado e/ou socializado, acarretando prejuízos ao desenvolvimento da ciência, da sociedade e das próprias instituições.

A maior parte das pesquisas científicas, produzidas nessas Instituições, no Brasil, está diretamente vinculada aos Programas de PósGraduação stricto sensu. Ao mesmo tempo em que esses Programas constituem o sistema educacional brasileiro, sendo responsáveis pela formação dos recursos humanos qualificados em ciência e tecnologia, respondem pela maior quantidade de pesquisas realizadas no país.
Para além do desenvolvimento das tecnologias da informação e da comunicação, que possibilitou aos pesquisadores veicularem seus achados de pesquisas científicas como bens culturais de domínio público, a partir do acesso em escala global, o acesso pelas camadas populares da sociedade aos resultados das pesquisas desenvolvidas no Ensino Superior ainda é um desafio. Adverte-nos Buarque $(1999$, p. 10) que,

\footnotetext{
Em que pesem esses avanços, os conhecimentos e os saberes gerados pela universidade continuam restritos, via de regra, aos segmentos mais privilegiados da população, não por culpa, mas, antes, devido aos modelos excludentes de desenvolvimento que sonegam às camada mais pobres a educação e os conhecimentos necessários à sua emancipação. Em decorrência disso, falta, ainda, para usar as palavras de Darcy Ribeiro, o norte orientador do roteiro de passos concretos, cada vez mais complexos, que nos levariam a criar uma universidade necessária ao desenvolvimento cultural autônomo do Brasil.
}

Programas de Pós-graduação que trabalham na perspectiva da formação profissional alteram muitos significados vividos por cada ator desse processo. Porém, nos adverte Maturana (1998, p 12) que "não se pode refletir sobre a educação sem antes, ou simultaneamente, refletir sobre essa coisa tão fundamental no viver cotidiano que é o projeto de país no qual 
estão inseridas nossas reflexões sobre a educação. Temos um projeto de país?" Sim, temos um projeto de país! Entretanto, devemos nos questionar sobre como estamos participando desse projeto e de que/qual país falamos. Assim, a produção do conhecimento científico implica em refletir acerca das concepções de pesquisa e sua difusão para a sociedade. Para Santos (2015, p. 05),

Embora a produção científica seja relevante para a avaliação das instituições de ensino superior, a divulgação científica dessa produção nem sempre é vista como prioridade nas IES brasileiras.

Geralmente está voltada a públicos e espaços especializados e, muitas vezes, carregada de jargões e termos específicos à área de abrangência do estudo, tornando-se publicações inacessíveis ao público leigo.

Entramos no século XXI com organizações educacionais modificadas, processos formativos docentes redefinidos e currículos repensados pelos atores da educação. Hoje, contamos com maior participação da sociedade organizada e acúmulo das discussões entre os atores envolvidos, cenário que levou à compreensão da necessária articulação entre as Instituições de Ensino Superior e o coletivo da sociedade.

No fluxo dessas mudanças, temos maior demanda pela difusão do conhecimento mais ampla para toda sociedade o que, certamente, segue nos desafiando para que $\circ$ conhecimento científico saia dos muros das Instituições que o produzem e envolvam a coletividade numa forte articulação entre o Ensino Superior e a população de nosso país. Se os resultados das pesquisas é um direito social, é dever das Instituições de Ensino Superior socializar sua produção científica.

\section{REFERÊNCIAS}

Buarque, C. (1999). Tendências da educação superior no século $X X I$. In: Conferência mundial sobre o ensino superior, 1998, Paris. Anais. Brasília, DF: UNESCO: CRUB

Maturana, R.H. (1998). Emoções e linguagens na educação e na política. Trad. Jose Fernando Camos Fontes. Belo Horizonte: Ed. UFMG

Santos, S.G. dos. (2015). Universidade e Produção do Conhecimento: um estudo sobre a difusão científica nos Programas de Pós-Graduação da UNEB. Universidade do Estado da Bahia. Programa de Pós-graduação Gestão e Tecnologias Aplicadas à Educação - GESTEC UNEB. Salvador 